\title{
RETENTION STRATEGIES AND PERFORMANCE OF UNIONISED ORGANISATIONS IN THE FOBTOB INDUSTRY IN LAGOS STATE
}

\author{
CHIDI,Christopher Odogwu \\ Department of Employment Relations and Human Resource Management, \\ Faculty of Management Sciences, University of Lagos, Nigeria \\ E-mail: krischidi2002@yahoo.com \&ochidi@unilag.edu.ng \\ DOI: 10.36108/ljerhrm/0202.02.0130
}

\begin{abstract}
The study examined the relationship between retention strategies and performance of organisations in the FOBTOB industry. The effect of retention strategies on performance of unionised organisations in the FOBTOB industry was also examined. The survey research design was adopted. A total of 420 research subjects were drawn from fourteen respondent companies using the simple random sampling and proportional stratified sampling techniques. The research instrument was subjected to validity and reliability tests. The domain of validity also called intrinsic validity was used for the validity estimate as well as content validity. The domain of validity was obtained by calculating the square root of reliability. The Cronbach Alpha was used for the reliability test. It was hypothesised that that there is no relationship between retention strategies and performance of unionised organisations in the industry studied. The result of hypothesis test shows that retention strategies are statistically and significantly related with all the measures of performance, such as growth in number of employees $(r=$ $0.370 ; p<0.01)$; profitability $(r=0.264 ; p<0.01)$; innovativeness $(r=0.279 ; p<0.01)$; performance stability $(r=0.241 ; p<0.01)$; and rate of sales $(r=0.207 ; p<0.01)$ while the Chisquare test result is $\left(\chi^{2}=231.507, d f=3, p<0.01\right)$ confirmed the results of the correlation test. It was also hypothesised that retention strategies do not affect performance of unionised organisations in the Industry studied. The results of the regression test revealed that retention strategies affect performance of unionised organisations in the FOBTOB industry. It is recommended that organisations should not rely only on intrinsic variables to influence employee retention; rather, a combination of both intrinsic and extrinsic variables should be considered as an effective retention strategy if optimal performance indices are to be achieved.
\end{abstract}

Keywords: Retention Strategies, Performance, Unionised Organisations, FOBTOB.

\section{Introduction}

Organisations require the right human resource capable of making positive impact on their performance. Organisational resources can be divided into three categories. The first are tangible assets, which include property, plant and equipment. The second are intangible assets, such as patents, trademarks and brand name recognition. The third and the most important, is the human capital. These three categories are also referred to as hardware, software and wetware (Brickley, Smith, Zimmerman\& Willett, 2003). According to Brickleyet al. (2003), hardware consists of physical assets; software is used to describe the firm's soft or intangible assets, such as formulae and recipes for creating value. Wetware refers to employee brainpower, that is; 'wet computers'. An organisation owns and can capture value from its hardware and software, but it only rents its 
wetware. Wetware is the private property of individual employees, who can take it with them to another organisation if they so choose (Brickley, Smith, Zimmerman \& Willett, 2003).

Thus, the most important of all organisational resources is the stock of human capital it acquires, deploys, and retains in pursuit of organisational outcomes such as profitability, market share, and customer satisfaction (Heneman \& Judge, 2006). Armstrong (2001) views retention strategies as how the organisation intends to keep the people it wants. Good retention practice goes hand-inhand with good recruitment and selection in an organisation and is part of a thread that runs through good and successful employers all the way from the time employees join the organisation through their induction, training and career progression (Cheatle, 2001). Cheatle further asserts that retention is traditionally appended to recruitment and selection because research has shown that success in retaining staff begins with the recruitment and selection process.

Employee retention strategies refer to the means, plan or set of decision-making behaviour put in place by organisations to retain their competent workforce for performance (Gberevbie, 2008). Samuel and Chipunza (2009) argue that the main purpose of retention is to prevent the loss of competent employees from leaving the organisation as this could have adverse effect on productivity and profitability. Dreher and Dougherty (2002) argue that voluntary turnover is costly because replacements must be recruited, selected and trained. Thus, an excessive voluntary turnover rate can disrupt the social and communication patterns among stayers and increase stayers' workloads and stress levels. The escalation in the rate of labour turnover is a grave concern for organisations. Dess and Shaw (2001) opine that voluntary turnover represents significant direct costs (replacement, recruitment, selection, management time and temporary staff); indirect costs (staff morale, pressure on remaining staff, cost of training, product/service quality and organisational reputation) and loss of social capital. Thus, studies such as this should be able to provide insights into how effective and efficient retention strategies could proffer solutions to these problems, with a view to achieving organisational performance. Researchers have used financial and non-financial metrics to determine organisational performance. The financial metrics include profit, sales, and market share. Non-financial metrics include output or productivity, quality, efficiency, attitudinal and behavioural measures such as commitment, intention to quit, and satisfaction (Khan, 2010).

The dimensions of organisational performance used in this study were adapted from Oghojafor, Lawal and Adebakin (2010) and Lawal (2011). Oghojaforet al. (2010) used profitability, growth rate, financial strength, performance stability, public image, staff morale, adaptability, innovativeness, social impact, level of debt, customers' patronage and ability to raise capital as performance measures with reliability coefficient of 0.96. Lawal (2011) used growth, sale, financial strength, operating efficiency, performance stability, public image, staff morale, adaptability, innovativeness, social impact, level of debt, customers' patronage and ability to raise capital as performance measures with reliability coefficient of 0.76 .

The objective of the study was to investigate the relationship between retention strategies and performance of organisations in the FOBTOB industry. The effect of retention strategies on performance of unionised organisations in the FOBTOB industry was also examined. 


\section{Literature Review}

This section examines the theoretical underpinnings which are germane to the study as well as some empirical review of literature bearing on employees' retention.

\section{Theoretical Framework of the Study}

\section{Herzberg's Two-Factor Theory}

Herzberg (1959) two factor theory as cited in Bassett-Jones and Lloyd (2005) argues that employees are motivated by internal values rather than values that are external to the work. In other words, motivation is internally generated and is propelled by variables that are intrinsic to the work which Herzberg calls "motivators". These intrinsic variables include achievement, recognition, the work itself, responsibility, advancement and growth. Conversely, certain factors cause dissatisfying experiences to employees; these factors largely result from non-job related variables (extrinsic). The theory explains that workers were motivated to higher performance through the content of the job, particularly achievement, recognition, advancement, autonomy, responsibility, and the work itself otherwise called satisfiers or motivators. On the other hand, the context of the job as exemplified by company policy and administration, supervision, salary and working conditions were observed to be dissatisfiers.

\section{Job Characteristics Theory}

Gomez-mejia, Balkin, and Cardy (2001) citing Hackman and Oldham (1980) opine that employees will be more motivated to work and more satisfied with their jobs to the extent that jobs contain certain core characteristics. The job characteristics theory identified five job dimensions. These are skill variety, task identity, task significance, autonomy and feedback. These are explained in what follows: skill variety (the degree to which the job requires the incumbent to do different tasks which involves the use of different skills); task identity (the degree to which the job requires the incumbent to do an identifiable piece of job with a visible outcome); task significance (the degree to which the job has a significant impact on others, both inside and outside of the organisation); autonomy (the degree of freedom, independence and discretion the incumbent has in planning and scheduling his work) and feedback (the degree to which the job provides the employee with clear and direct information about job outcomes and performance).

\section{Equity Theory or Justice Theory}

Equity theory is concerned with inputs and outputs comparisons of significant others.Dessler (2008) argues that organisational justice has three components- distributive justice, procedural justice and interpersonal (interactional or interactive) justice. Adams (1965), distinguished between distributive and procedural justice. Distributive equity or justice is concerned with the fairness with which people feel they are rewarded in accordance with their contribution and in comparison with others; and procedural equity or procedural justice is concerned with the perceptions employees have about the fairness with which procedures in such areas as performance appraisal, promotion and discipline are being operated.

\section{Empirical Review of Literature}

In a study of employee retention in Nestlé Nigeria Plc. Gberevbie (2008), identified the following retention strategies; good salary structure, good condition of service, free medical services for staff, spouse and four children; staff recognition in decision making on issues 
affecting their welfare, provision of staff bus, ability of management to fulfill promises made to staff, end-of-year bonus, extra pay for meeting sales targets, conducive working environment, confirmation of staff appointment in six months after successful confirmation interview, prompt payment of pension and gratuity, international exchange programmes and adequate training.

Thio's (2000) study on retention strategies in turbulent times, using Singapore Anglican Welfare Council (a voluntary welfare organisation) as a test case found that high and unexpected turnover can be a reflection of negative job attitudes and low staff morale and may be mitigated by counter measures. These measures include regular in-service training, participative management, communication, grievance handling mechanism, job design through job rotation, job enlargement and enrichment, suggestion scheme, achievement recognition awards, feedback on staff performance, mentoring, and improved staff selection approaches.

Abassi and Hollman (2000) opine that if jobs provide adequate financial incentives, the more likely employees remain with the organisation. They argue that poor hiring practices, poor managerial style, lack of recognition, lack of competitive compensation system and toxic work environment make employees to quit from an organisation. Hausknecht, Rodda and Howard (2008) developed a content model of employee retention that is grounded in theory and past research. Their study reviewed the major theories that have been advanced in the literature over the last 50 years that explain why employees stay or quit. Their study listed the following twelve retention factors: advancement opportunities, constituent attachments, extrinsic rewards, flexible work arrangement, investments (length of service), job satisfaction, lack of alternatives, location, non-work influences, organisational commitment, organisational justice and organisational prestige. They found that the retention reason mentioned most frequently was job satisfaction followed by extrinsic rewards.

Ongori (2007) observed that human capital management factors provide a core set of measures that management can use to improve overall corporate performance. These are employee engagement, the organisation's capacity to engage, retain and optimise the value of its employees lies in how well job is designed and support that is shown to employees by management. These would motivate employees to stay in the organisation. Ongori further pointed out that high labour turnover may mean poor personnel policies, poor recruitment policies, poor supervisory policies, lack of promotion inter alia. To retain employees, management should address the above problems causing employees to leave.

Griffeth, Hom and Gaertner (2000), noted that pay and pay-related variables have a great effect on employee turnover. Therefore, management should compensate employees adequately and equitably with a view to retaining high performers. Taplin, Winterton and Winterton (2003), in a study of British clothing industry observed that the employer initiatives to reduce turnover included a range of measures such as improving remuneration packages, rigorous screening procedures for new hires, improved training programmes, flexible working hours and employee participation. There is evidence to show that on the average, employers who offer the most attractive reward packages have lower attrition rates than those who pay poorly (Gomez-Mejia \&Balkin, I992).

Empirical study by Maertz and Griffeth (2004) revealed that extrinsic factors such as competitive salary, good interpersonal relationships, friendly working environment and job security were 
cited by employees as key motivational variables that influenced their retention in the organisations. The implication of this therefore is that management should not rely only on intrinsic variables to influence employee retention; rather, a combination of both intrinsic and extrinsic variables should be considered as an effective retention strategy. Wanous (1989) recommended realistic job preview (RJP) as a retention strategy. This entails divulging to applicants the negative as well as the positive aspects of the job. The essence is to reduce undue high expectations on the part of applicants as dissatisfaction and labour turnover may result contrariwise. Realistic job preview is a recruitment strategy designed to halt unwanted turnover among new workers who did not understand the expectations of their job when they were hired.

It is designed to reduce early turnover by communicating both the desirable and undesirable aspects of a job before applicants are given a job offer. In a study by Steel, Griffeth and Hom (2002), realistic job preview was identified as one of the effective retention strategies. Others are survey feedback and job enrichment. Exit interviews proved to be an ineffective retention strategy. The IDS (2004), suggested that one of the retention strategies to curb general turnover problem within the organisation is to improve recruitment procedures to ensure that candidates receive a realistic impression of the company and the job. Realistic job preview involves giving an applicant an honest assessment of a job (Aamodt, 1999).

As reported by Taylor (1994), realistic job preview in a trucking company increased job satisfaction and reduced annual turnover from 207 per cent to 150 per cent. The logic behind realistic job previews is that even though telling the truth scares away many applicants especially the most qualified ones (Bretz\& Judge, 1998; Saks, Wiesner \& Summers, 1996); the ones who stay will not be scared of the demands of the job. Thus, well-informed applicants will tend to stay on the job longer than applicants who did not understand the nature of the job (Aamodt, 1999). CIPD (2004) reported that 85 per cent of the organisations surveyed experienced recruitment difficulties. With recruitment becoming so challenging, retaining existing employees has become a key business issue.

In a study on employee retention strategies and organisational performance, Gberevbie (2008) found that there is a relationship between employee retention strategies and organisational performance. Okoh (1998) found that there is a relationship between employee motivation, retention and organisational performance. When employees are motivated, there is the tendency for them to remain with the organisation to give off their best to their jobs with a view to achieving the goals of the organisation. Pfeffer (1994) argues that a greater use of specified practices, such as participation and empowerment, incentive pay, employment security, promotion from within, training and skill development, will result in higher productivity and profit across all types of organisation. Aamodt (2007) opines that employees come to an organisation with certain expectations about a variety of issues, such as pay, working conditions, opportunity for advancement, and organisational culture. When reality does not match these expectations, employees become less satisfied and as a result are more likely to leave an organisation. Aamodt opines that turnover arising from unmet expectations can be reduced through the following retention mechanisms:

i. conducting realistic job previews during the recruitment stage 
ii. select employees who have been referred by a current employee who have friends and /or family working for the organisation, and who did not leave their previous job after only a short tenure

iii. meet employee needs(safety, social, growth)

iv. provide a good work environment

v. provide opportunities for advancement

vi. provide a competitive pay and benefits package

vii. look for a good person/organisation fit during the selection interview

Armstrong (2006) found that the key factors affecting job satisfaction were career opportunities, job influence, teamwork and job challenge. Luthans (1998, p.144) posits that "work itself, pay, supervision, coworkers and promotion opportunities are variables which influence job satisfaction". In their study of faculty workload, compensation management and academics quality in higher education in Pakistan; Shahzad, Mumtaz, Hayat and Khan (2010) found that an academic who is facing financial constraints in his/her pay would not be satisfied with his/her job. Low pay affects job satisfaction negatively. While high pay affects job satisfaction positively. Thus, low pay leads to job dissatisfaction. Mathis and Jackson (2004, p.95) argue that "continuity of employees provides better employee image for attracting and retaining other individuals."

Mathis and Jackson (2004) posit that numerous surveys and experiences of human resource management professionals reveal that one key to retention is to have competitive compensation practices. Many managers believe that money is the prime retention factor, 89 percent of respondents in one survey cited better pay or higher compensation as a reason for leaving one employer for another (Marks, 2001). Steel, Griffeth and Hom (2002) argue that survey feedback, job enrichment and realistic job previews are effective retention strategies. Equitable pay, realistic job preview, induction/orientation, family-friendly $H R$ practices, training and development, effective leadership, job design, and employee survey have been cited as retention strategies (Torrington, Hall \& Taylor, 2008). McEvoy and Cascio (1987) observed that many writers agree that while realistic job preview do reduce turnover, they should not be regarded as a primary solution. Changes in compensation, supervisory behaviour, and job assignments are more effective long- term solutions (Gatewood \&Feild, 2001).

Armstrong (2012, p.245), posits that "retention strategies should be based on an understanding of the factors that affect whether or not employees leave or stay." Armstrong further asserts that for early-career employees (30 years old and under), career advancement is significant. For midcareer employees (aged 31-50), the ability to manage their careers and satisfaction from their work are important. Late-career employees (aged over 50) will be more interested in security. Thus, age is an important variable in changing jobs and employers. As was observed by Armstrong, younger workers are more likely to change jobs and employers more often than older workers. Factors that affect retention are company image, recruitment and selection, leadership, learning opportunities as well as performance recognition and rewards (Armstrong, 2012). 


\section{Research Hypotheses:}

Ho1: There is no relationship between retention strategies and performance of unionised organisations in the Food, Beverage and Tobacco Industry in Lagos State.

Ho$_{2}$ : Retention strategies do not affect performance of unionised organisations in the Food, Beverage and Tobacco Industry in Lagos State.

\section{Methods}

\section{Study Site and Research Design}

The site for the study is Lagos State, situated in the South-Western part of Nigeria. Lagos State is Nigeria's financial, commercial and economic capital, with the largest concentration of unionised organisations in the Food, Beverage and Tobacco Industry. Besides, Lagos is the most urbanised State in Nigeria. The adopted research design is the survey method. The justification for choosing the survey method is based on the fact that the study is interested in gaining an understanding of the problem being investigated (Ezirim, Briggs \&Maclayton, 2004) without any attempt to manipulate or control the sample subjects (Asika,1991). More so, the study is interested in the attitude or opinion of the respondents as opposed to their behaviour. The survey method is ideal since large sample of respondents are required and the researcher is interested in subjecting the collected data to rigorous statistical (hypothesis) testing. More so, it is economical.

\section{Participants/Sample}

Participants for the study consist of senior and management staff in the Food, Beverage and Tobacco Industry in Lagos State. The target respondents for the survey were the executive management and senior employees in charge of human resource management functions. The size of the target population from the selected companies was less than 1,000,000. There were 80 companies in the fold of the Association of Food, Beverage and Tobacco Employers (AFBTE) in Nigeria as obtained from the directory of member-companies as of the time of this study. Of this number, 54 companies are located in Lagos. A total of fourteen (14) respondent companies were drawn from the directory of companies using the simple random sampling technique. The stratified random sampling was further adopted to determine individual respondents at different job levels. Researchers use stratified random sampling to ensure that different groups of a population are adequately represented in the sample so as to increase the level of accuracy when estimating parameters (Frankfort-Nachmias\&Nachmias, 2009).

In this study, the proportional stratified sampling was used to select equal sample of thirty (30) from each of the organisations surveyed. A total of four hundred and twenty (420) research subjects were drawn from fourteen respondent companies. The sampling technique and sample size were employed in order to have representation of the various cadres of staff because the population does not constitute a homogenous group (Briggs, 2007; Kothari, 2004). The sampled companies are Cadbury Nig. PLC, Guinness Nig PLC, Nigerian Bottling Company PLC, West African Seasoning Co. Ltd, Niger Biscuit Co. Ltd., Seven-Up Bottling Co. PLC, Nigerian Breweries PLC, Ragolis Waters Ltd., Promasidor Nig. Ltd., OK Foods Ltd., Nestlé Nig. PLC, Flour Mills Nig. PLC, Friesland Foods (WAMCO) Nig, PLC and GlaxoSmithKline Consumer Nig. PLC. However, 284 copies of questionnaire were properly completed and used for data analysis. This represents 68 per cent response rate. 
TABLE 3.1: ORGANISATIONS SAMPLED

\begin{tabular}{|c|c|c|c|}
\hline $\mathrm{S} / \mathrm{N}$ & ORGANISATIONS SAMPLED & $\begin{array}{l}\text { NUMBER } \\
\text { SUBJECTS }\end{array}$ & OF \\
\hline 1. & Cadbury Nig. PLC & 30 & \\
\hline 2. & Guinness Nig PLC & 30 & \\
\hline 3. & Nigerian Bottling Company PLC & 30 & \\
\hline 4. & West African Seasoning Co. Ltd & 30 & \\
\hline 5. & Niger Biscuit Co. Ltd & 30 & \\
\hline 6. & Seven-Up Bottling Co. PLC & 30 & \\
\hline 7. & Nigerian Breweries PLC & 30 & \\
\hline 8. & Ragolis Waters Ltd & 30 & \\
\hline 9. & Promasidor Nig. Ltd & 30 & \\
\hline 10. & OK Foods Ltd & 30 & \\
\hline 11. & Nestlē Nig. PLC & 30 & \\
\hline 12 & Flour Mills Nig. PLC & 30 & \\
\hline 13 & Friesland Foods (WAMCO) Nig, PLC & 30 & \\
\hline 14 & GlaxoSmithKline Consumer Nig. PLC & 30 & \\
\hline & Total & 420 & \\
\hline
\end{tabular}

Source: Field Survey, 2016

With respect to sample size, varied viewpoints have been advanced by experts in this regard. Some experts have suggested that the sample size should be five per cent of the population of study. Others hold the view that 10 per cent is ideal. This study used 25 per cent of the number of companies in the directory as sample. That is, 14 out of 54 companies operating in Lagos State. A common rule of thumb for an initial estimate of the appropriate sample size is provided by Sherman (2017) as follows: for smaller with the population less than 100, census the entire population. If the population is plus or minus 500, sample 50 per cent of the population. If the population is plus or minus 1,500; sample 20 per cent of the population. For a population greater than 5,000, sample 400 members of the population (Sherman, 2017). According to Mitchel and Jolley (2008), the total sample size of 500 staff is adequate and representative for a population size of less than $1,000,000$ workers.

\section{Instrument}

The instrument was designed using opinion and factual questions or categorical questions. The Likert 4-point scale ranging from strongly agree (4) to strongly disagree (1) was adopted for opinion questions to elicit information from respondents. The instrument is comprised of two sections with alphabetical numbering. Section A x-rayed the socio-demographic characteristics of respondents. Section B sought the views of respondents regarding retention strategies in their organisations. The research instrument was subjected to validity and reliability testing. Asika (1991) posits that validity is superior to reliability, and that both are useful in ascertaining the usefulness of measuring instruments. Validity is the ability of the research instrument or scale to measure what it is designed to measure (Asika, 2004). The domain of validity also called intrinsic validity was used for the validity estimate as well as content validity. The domain of validity was obtained by calculating the square root of reliability (Guilford, 1954; Uwaoma, 
Udeagha\&Madukwe, 2011). Validity estimate is 0.79 while the Cronbach's Alpha is 0.62 being the reliability coefficient of the instrument. An alpha level of 0.60 and above is generally considered satisfactory internal consistency (Asika, 1991).

\section{Data Analyses}

Data analyses were done using Statistical Product and Service Solutions (Ho, 2006); formerly Statistical Package for the Social Sciences (SPSS) software version 20. Frequency distribution showing absolute and relative frequencies or percentages was adopted as well as pictorial representation or visual displays of data such as bar charts. The hypothesis for the study was tested using the Pearson's Product Moment Correlation and Regression Model and at 5 per cent level of significance and Chi-square test.

\section{RESULTS}

\section{TABLE 4.1: SOCIO-DEMOGRAPHIC CHARACTERISTICS OF RESPONDENTS}

\section{S/N VARIABLES}

\section{Sex of Respondents:}

1.

Male

Female

\section{Age of Respondents:}

2. 20-29

30-39

40-49

50 and above

\section{Marital Status:}

3. Married

Single

Separated

Divorced

Qualifications:

OND

4. HND

First degree

Master's degree

Ph.D.

Professional diploma Others(Pls. specify)

5. Job Category:

Junior

Senior

Management Staff

\section{ABSOLUTE FREQUENCY}

207

77

72.9

27.1

RELATIVE

FREQUENCY (\%)
13.4

54.9

29.9

1.8

68.7

29.2

0.7

1.4

4.2

28.9

40.5

25.7

0.4

$---$

0.4

79.9

79.9

20.1 
6. Organisational Size:

Less than 50 staff

50-100 staff

101-250 staff

37

13

251-500 staff

58

20.4

$501 \&$ above

189

66.5

What is the union status of

7. your organisation?

Unionised

Non-unionised

8. How long have you been

working for your organisation?

(Please specify in years)

Less than 5years

5-10years

11-15years

16years and above

No Response

Source: Field Survey, 2016

Table 4.1 reveals that 72.9 per cent of the respondents are males; while 27.1 per cent are females. This indicates that there are more male than female respondents. About 55 percent of respondents are in the age bracket of 30-39 and they constitute the largest number of respondents. This sector has many younger workers below 40 years old and this constitutes 68.3 per cent. The marital status shows the preponderance of married respondents with 68.7 per cent. With respect to educational qualifications, 40.5 per cent of respondents possess first degree, 28.9 per cent of respondents hold the HND and 25.7 percent are holders of Master's degree. In a nutshell, 66.6 per cent of the respondents possess university degrees. With respect to job category, 79.9 per cent are senior staff while 20.1 percent are management staff. As regards organisational size, 66.5 per cent of respondents belong to organisations with membership size of 501 and above. This is followed by 20.4 percent for 251-500 membership size and 13 per cent for 101-250 membership size. With respect to union status, 100 per cent of respondents are from unionised organisations. 
TABLE: 4.2 PERCEPTIONS OF RESPONDENTS ON RETENTION STRATEGIES

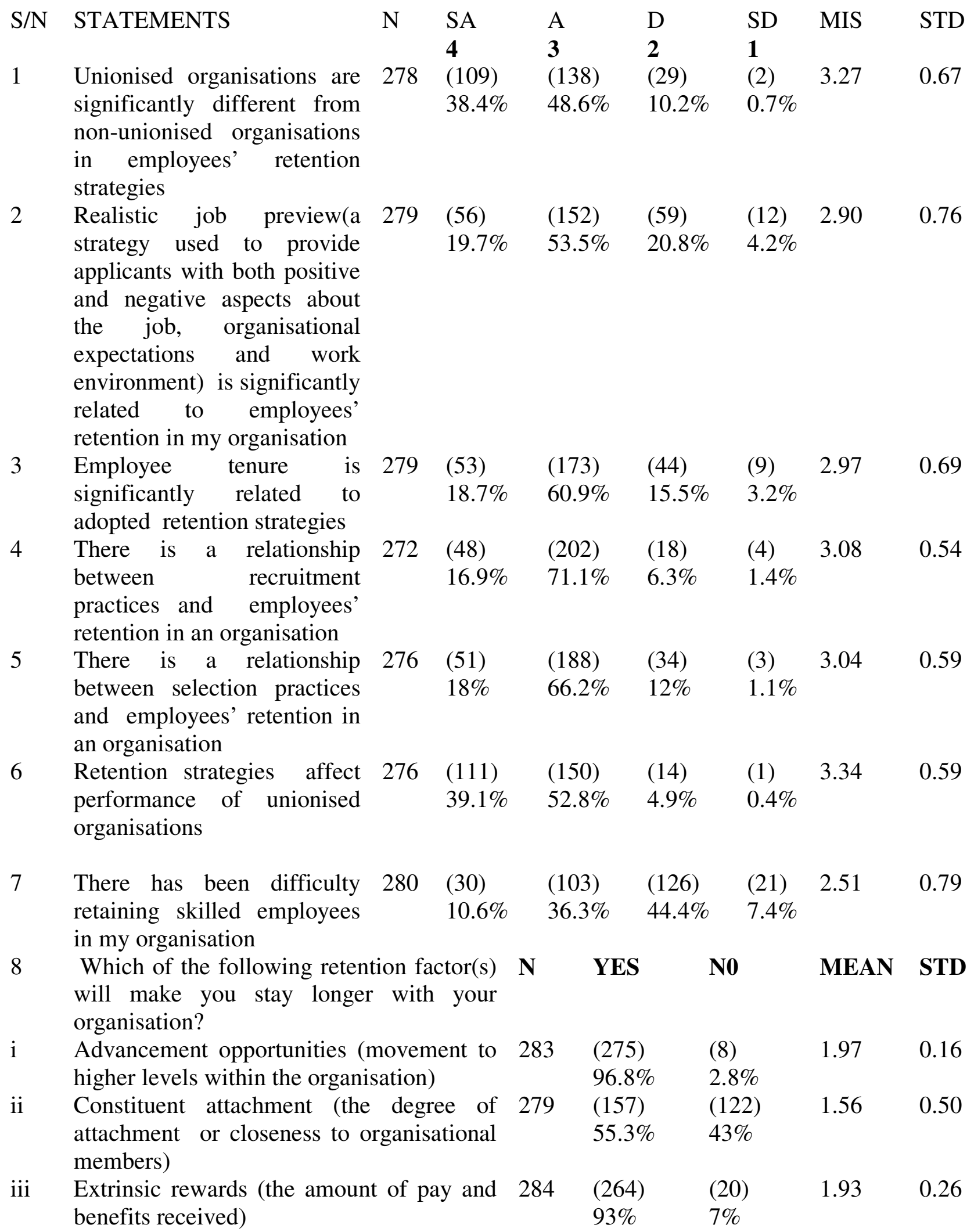




\begin{tabular}{|c|c|c|c|c|c|c|}
\hline iv & $\begin{array}{l}\text { Flexible work arrangement (nature of } \\
\text { work schedule or hours) }\end{array}$ & 284 & $\begin{array}{l}(249) \\
87.7 \%\end{array}$ & $\begin{array}{l}(35) \\
12.3 \%\end{array}$ & 1.88 & 0.33 \\
\hline $\mathrm{V}$ & $\begin{array}{l}\text { Investment (length of service to the } \\
\text { organisation) }\end{array}$ & 284 & $\begin{array}{l}(202) \\
71.1 \%\end{array}$ & $\begin{array}{l}(82) \\
28.9 \%\end{array}$ & 1.71 & 0.45 \\
\hline vi & $\begin{array}{l}\text { Job satisfaction (degree to which } \\
\text { individuals like their jobs) }\end{array}$ & 284 & $\begin{array}{l}(264) \\
93 \%\end{array}$ & $\begin{array}{l}(20) \\
7 \%\end{array}$ & 1.93 & 0.26 \\
\hline vii & $\begin{array}{l}\text { Lack of alternatives (unavailability of jobs } \\
\text { outside the organisation) }\end{array}$ & 282 & $\begin{array}{l}(180) \\
63.4 \%\end{array}$ & $\begin{array}{l}(102) \\
35.9 \%\end{array}$ & 1.64 & 0.48 \\
\hline viii & $\begin{array}{l}\text { Location (Nearness of the workplace } \\
\text { relative to one's home) }\end{array}$ & 283 & $\begin{array}{l}(190) \\
66.9 \%\end{array}$ & $\begin{array}{l}(93) \\
32.7 \%\end{array}$ & 1.67 & 0.47 \\
\hline ix & $\begin{array}{l}\text { Organisational commitment (degree to } \\
\text { which individual's identify with and are } \\
\text { involved in the organisation) }\end{array}$ & 282 & $\begin{array}{l}(261) \\
91.9 \%\end{array}$ & $\begin{array}{l}(21) \\
7.4 \%\end{array}$ & 1.93 & 0.26 \\
\hline $\mathrm{X}$ & $\begin{array}{l}\text { Organisational justice(fairness of reward } \\
\text { allocations, policies and interpersonal } \\
\text { treatment) }\end{array}$ & 283 & $\begin{array}{l}(266) \\
93.7 \%\end{array}$ & $\begin{array}{l}(17) \\
6 \%\end{array}$ & 1.94 & 0.24 \\
\hline xi & $\begin{array}{l}\text { Organisational prestige (organisational } \\
\text { reputation/goodwill) }\end{array}$ & 283 & $\begin{array}{l}(256) \\
90.1 \%\end{array}$ & $\begin{array}{l}(27) \\
9.5 \%\end{array}$ & 1.90 & 0.29 \\
\hline xii & $\begin{array}{l}\text { Non-work influences (existence of } \\
\text { responsibilities and commitments outside } \\
\text { the organisation) }\end{array}$ & 271 & $\begin{array}{l}(179) \\
63 \%\end{array}$ & $\begin{array}{l}(93) \\
32.7 \%\end{array}$ & 1.66 & 0.48 \\
\hline
\end{tabular}

Source: Field Survey, 2016

From Table 4.2 it can be seen that retention strategies affect performance of unionised organisations with a mean item score of 3.34 and a standard deviation of 0.59 . With respect to union status and employees' retention, 87 per cent of the respondents agreed and strongly agreed that unionised organisations are significantly different comparable to non-unionised organisations in employees' retention strategies. This statement has a mean item score of 3.27 and a standard deviation of 0.67 . Of the 279 respondents to this statement, 73.2 per cent agreed and strongly agreed that realistic job preview (a strategy used to provide applicants with both positive and negative aspects about the job, organisational expectations and work environment) is significantly related to employees' retention in their organisations.

Of the 279 respondents to this statement, 79.6 per cent are of the view that employee tenure is significantly related to adopted retention strategies. Of the 276 respondents, 84.2 per cent agreed and strongly agreed that there is a relationship between selection practices and employees' retention in their organisations. This statement has a mean item score of 3.04 and a standard deviation of 0.59 . Also, from descriptive statistics in Table 4.2; it can be observed that retention strategies affect performance of unionised organisations with a mean item score of 3.34 and a standard deviation of 0.59 . The study revealed that realistic job preview is significantly related to employees' retention. It was found that unionised organisations are significantly different from non-unionised organisations in employees' retention strategies. One of the findings of the study is that employee tenure is significantly related to adopted retention strategies. The study also found that there is a relationship between recruitment practices, selection practices and employees' retention. With respect to retention factors, the study found that advancement 
opportunities, organisational justice, extrinsic rewards, job satisfaction, organisational commitments and organisational prestige are mostly preferred retention factors that could induce workers to stay longer with their organisations.

Of the twelve retention factors used in the study, 96.8 per cent of the respondents agreed that advancement opportunities (movement to higher levels within the organisation) will make them to stay longer with their organisations; followed by organisational justice(fairness of reward allocations, policies and interpersonal treatment); extrinsic rewards (the amount of pay and benefits received); job satisfaction (degree to which individuals like their jobs); Organisational commitment (degree to which individual's identify with and are involved in the organisation); and organisational prestige ( organisational reputation/goodwill).

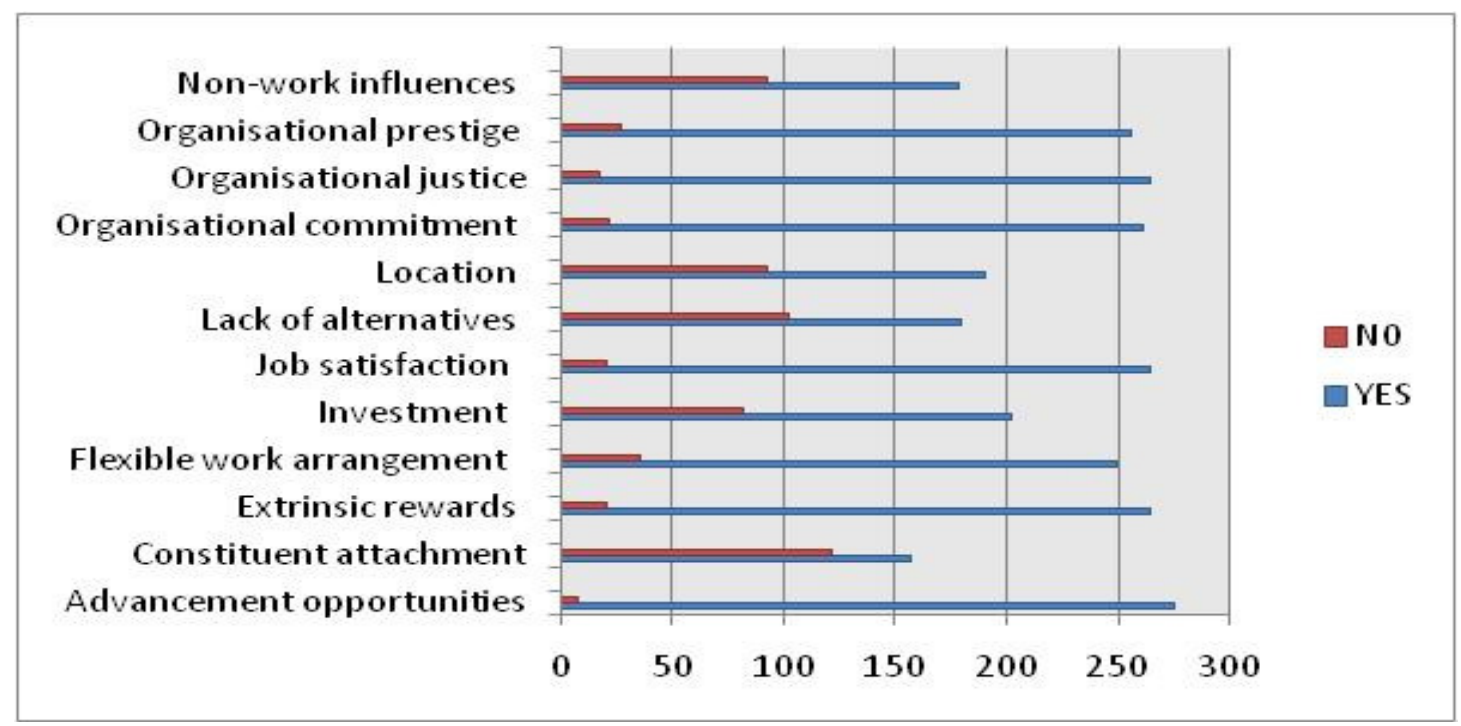

Source: Generated by the Author from Table 4.2

Fig 4.1: Bar Chart of Retention Strategies

It was hypothesised that there is no relationship between retention strategies and performance of unionised organisations in the FOBTOB industry. From the test of hypothesis, it was found that there is statistically and significant relationship between retention strategies and performance of unionised organisations in the Food, Beverage and Tobacco Industry in Lagos State. Retention strategies are positively and significantly related with all the measures of performance. Such as growth in number of employees $(\mathrm{r}=0.370 ; p<0.01)$; profitability $(\mathrm{r}=0.264 ; p<0.01)$; innovativeness $(\mathrm{r}=0.279 ; \mathrm{p}<0.01)$; performance stability $(\mathrm{r}=0.241 ; p<0.01)$; staff morale $(\mathrm{r}=$ $0.242 ; p<0.01)$; operational efficiency $\mathrm{r}=0.204 ; p<0.01)$; market share $(\mathrm{r}=0.152 ; p<0.01)$; adaptability $(\mathrm{r}=0.259 ; p<0.05)$; public image $(\mathrm{r}=0.217 ; p<0.01)$; and rate of sales $(\mathrm{r}=0.207$; $p<0.01)$. The Chi-square test of goodness-of-fit also confirms that there is a nexus between retention strategies and performance of unionised organisations $\left(\chi^{2}=231.507, d f=3, p<0.01\right)$. 


\section{TABLE: 4.3 REGRESSION RESULTS}

S/N Measures of Performance

1. Rate of Sales

2. Operational Efficiency

3. Performance Stability

4. Public Image

5. Staff Morale

6. Innovativeness
Overall Model Summary

$\mathrm{R}=0.390$

$\mathrm{R} 2=0.152$

$(\mathrm{F}=9.573 ; \mathrm{p}<.01)$

$\mathrm{R}=0.322$

$\mathrm{R} 2=0.104$

$(\mathrm{F}=6.197 ; \mathrm{p}<.01)$

$\mathrm{R}=0.355$

$\mathrm{R} 2=0.126$

$(\mathrm{F}=7.738 ; \mathrm{p}<.01)$

$\mathrm{R}=0.428$

$\mathrm{R} 2=0.183$

$(\mathrm{F}=12.003 ; \mathrm{p}<.01)$

$\mathrm{R}=0.408$

$\mathrm{R} 2=0.167$

$(\mathrm{F}=10.681 ; \mathrm{p}<.01)$

$\mathrm{R}=0.382$

$\mathrm{R} 2=0.146$

$(\mathrm{F}=9.110 ; \mathrm{p}<.01)$

7. Growth rate of number of $\mathrm{R}=0.426$ employees

$\mathrm{R} 2=0.181$

$(\mathrm{F}=11.821 ; \mathrm{p}<.01)$

8. Adaptability

$\mathrm{R}=0.328$

$\mathrm{R} 2=107$

$(\mathrm{F}=6.451 ; \mathrm{p}<.01)$

9. Market Shares

$\mathrm{R}=0.216$

$\mathrm{R} 2=0.047$

$(\mathrm{F}=2.624 ; \mathrm{p}<.0 .05)$

10 Profitability

$\mathrm{R}=0.317$

$\mathrm{R} 2=0.101$

$(\mathrm{F}=5.986 ; \mathrm{p}<0.01)$

Legend: $\mathrm{ns}=$ non-significant $\quad \mathrm{s}=$ significant
Retention Strategies

$\beta=0.105$

$\mathrm{t}$-value $=1.684$

$\mathrm{p}$-value $=0.093$

Remark: ns

$\beta=0.107$

t-value $=1.670$

$\mathrm{p}$-value $=0.096$

Remark: ns

$\beta=0.128$

$\mathrm{t}$-value $=2.015$

$\mathrm{p}$-value $=.045$

Remark: s

$\beta=0.093$

$\mathrm{t}$-value $=1.525$

$\mathrm{p}$-value $=0.129$

Remark: ns

$\beta=0.138$

$\mathrm{t}$-value $=2.233$

$\mathrm{p}$-value $=0.026$

Remark: $\mathrm{s}$

$\beta=0.214$

$\mathrm{t}$-value $=3.417$

$\mathrm{p}$-value $=0.001$

Remark: s

$\beta=0.334$

$\mathrm{t}$-value $=5.432$

$\mathrm{p}$-value $=0.000$

Remark: s

$\beta=0.203$

$\mathrm{t}$-value $=3.169$

$\mathrm{p}$-value $=0.002$

Remark: s

$\beta=0.132$

$\mathrm{t}$-value $=1.995$

$\mathrm{p}$-value $=0.047$

Remark: s

$\beta=0.208$

$\mathrm{t}$-value $=3.235$

$\mathrm{p}$-value $=0.001$

Remark: s 
Similarly, from Table 4.3; it could be observed from the results of the regression analysis that retention strategies affect performance of unionised organisations in the Food, Beverage and Tobacco Industry in Lagos State.

\section{Discussion of Findings}

The results of the study are consistent with the literature. According to Samuel and Chipunza (2009), the main purpose of retention is to prevent the loss of competent employees from leaving the organisation as this could have adverse effect on productivity and profitability. Researchers have found that employees are more likely to remain and work for the successful achievement of organisational goals when appropriate employee retention strategies are adopted and implemented by organisations (Gberevbie, 2008).

Thio (2000) in a study on retention strategies in turbulent times, using Singapore Anglican Welfare Council (a voluntary welfare organisation) as a test case found that high and unexpected turnover can be a reflection of negative job attitudes and low staff morale and may be mitigated by counter measures. These measures included regular in-service training, participative management, communication, grievance handling mechanism, job design through job rotation, job enlargement and enrichment, suggestion scheme, achievement recognition awards, feedback on staff performance, mentoring, improved staff selection approaches are indeed imperative as part of getting a goodness-of-fit between the worker and the strategic and operational problems of the organisation.

It was found that realistic job preview is significantly related to employees' retention. This finding is consistent with the findings of Griffeth and Hom (2002), who found that realistic job preview, was identified as one of the effective retention strategies. The IDS (2004), suggested that one of the retention strategies to curb general turnover problem within the organisation is to improve recruitment procedures to ensure that candidates receive a realistic impression of the company and the job. Realistic job preview involves giving an applicant an honest assessment of a job (Aamodt, 1999). As reported by Taylor (1994), realistic job preview in a trucking company increased job satisfaction and reduced annual turnover from 207 percent to 150 percent. The logic behind realistic job previews is that even though telling the truth scares away many applicants especially the most qualified ones (Bretz\& Judge, 1998; Saks, Wiesner \& Summers, 1996) the ones who stay will not be surprised about the demands of the job. Thus, well-informed applicants will tend to stay on the job longer than applicants who did not understand the nature of the job (Aamodt, 1999).

It was found that unionised organisations are significantly different from non-unionised organisations in employees' retention strategies. This finding is in line with Freeman and Medoff (1984) who found that unionised firms tend to retain their employees longer than non-union firms. This is partly explained by the fact that unionised firms pay their employees higher wages and are involved in the welfare issues of their members. More so, the union is seen as representing employees' voice.

With respect to retention factors, it was found that advancement opportunities, organisational justice, extrinsic rewards, job satisfaction, organisational commitments and organisational prestige are mostly preferred retention factors that could induce workers to stay longer with their organisations. This finding is consistent with the literature. Hausknecht, Rodda and Howard 
(2008) developed a content model of employee retention. Their study listed the following twelve retention factors; advancement opportunities, constituent attachments, extrinsic rewards, flexible work arrangement, investments(length of service), job satisfaction, lack of alternatives, location, non-work influences, organisational commitment, organisational justice and organisational prestige. They found that the retention reason mentioned most frequently was job satisfaction followed by extrinsic rewards.

Aamodt (2007) opines that employees come to an organisation with certain expectations about a variety of issues, such as pay, working conditions, opportunity for advancement, and organisational culture. According to Armstrong (2006) research findings found that the key factors affecting job satisfaction were career opportunities, job influence, teamwork and job challenge. Luthans (1998) posits that work itself, pay, supervision, coworkers and promotion opportunities are variables which influence job satisfaction. In their study of faculty workload, compensation management and academics quality in higher education in Pakistan; Shahzad, Mumtaz, Hayat and Khan (2010) found that an academic who is facing financial constraints in his/her pay would not be satisfied with his/her job.

Empirical study by Maertz and Griffeth (2004) revealed that extrinsic factors such as competitive salary, good interpersonal relationships, friendly working environment, and job security were cited by employees as key motivational variables that influenced their retention in the organisations. Armstrong further asserts that for early-career employees (30 years old and under), career advancement is significant. For mid-career employees (aged 31-50), the ability to manage their careers and satisfaction from their work are important. Late-career employees (aged over 50) will be more interested in security. Factors that affect retention are company image, recruitment and selection, leadership, learning opportunities as well as performance recognition and rewards (Armstrong, 2012).

\section{Conclusion and Recommendations}

This study investigated the effect of retention strategies on performance of unionised organisations in the Food, Beverage and Tobacco Industry in Lagos State. From the test of hypothesis, it was found that retention strategies affect performance of unionised organisations in the Food, Beverage and Tobacco Industry in Lagos State. Retention strategies are positively and significantly associated with all the measures of performance. For organisations to achieve quantum leap in their performance indices; it is hereby recommended that they should not rely only on intrinsic variables to influence employee retention; rather, a combination of both intrinsic and extrinsic variables should be considered as an effective retention strategy. The use of realistic job preview should be encouraged as a retention strategy. Retention strategies such as advancement opportunities, extrinsic rewards, job satisfaction as well as organisational justice should be put in place by organisations to curb employees' separation. 


\section{References}

Aamodt, M.G. (1999). Applied industrial/ organisational psychology ( $3^{\text {rd }}$ ed.). London: Wadsworth Publishing Company.

Aamodt, M.G. (2007). Industrial/organisational psychology: An applied approach (5 ${ }^{\text {th }}$ ed.). Belmont-USA: Thomson Wadsworth.

Abassi, S.M., \& Hollman, K.W. (2000). Turnover: The real bottom line. Public Personnel Management,2(3), 333-342.

Adams, J.S. (1965). Inequity in social exchange. In L. Berkowitz, (Ed.). Advances in Experimental Social Psychology (pp. 267-299). New -York: Academic Press

Armstrong, M. (2001). A hand book of human resources management practice $\left(8^{\text {th }} \mathrm{ed}.\right)$. London: Kogan Page Ltd.

Armstrong, M. (2006). A handbook of human resource management practice (10 $\left.{ }^{\text {th }} \mathrm{ed}.\right)$. London: Kogan Page Ltd.

Armstrong, M. (2012). Armstrong's handbook of human resource management practice(12 ${ }^{\text {th }} \mathrm{ed}$.). London: Kogan Page Ltd.

Asika, N. (1991). Research methodology in the behavioural sciences. Lagos: Longman Nigeria PLC.

Asika, N. (2004). Research methodology: A process approach. Lagos: Mukugamu\& Brothers Enterprises.

Bassett-Jones, N., \& Lloyd, G.C. (2005). Does Herzberg's motivation theory have staying power? Journal of Management Development,24(10), 929-943.

Bretz, R.D., \& Judge, T. A. (1998). Realistic job previews: A test of the adverse self-selection hypothesis. Journal of Applied Psychology, 83(2), 330-337.

Brickley, J. A., Smith, C. W, Zimmerman, J. L., \& Willett, J. (2003). Designing organisations to create value: From structure to strategy. New York: McGraw - Hill.

Briggs, B.R. (2007). Problems of recruitment in civil service: Case of the Nigerian civil service. African Journal of Business Management, 16,142-153.

Chartered Institute of Personnel \& Development (2004).Recruitment, retention and labour turnover survey. London: CIPD.

Cheatle, K. (2001). Mastering human resource management. New York: Palgrave.

Dess, G.G., \& Shaw, J.D. (2001). Voluntary turnover, social capital and organisational performance. Academy of Management Review, 26(3), 446-456.

Dessler, G. (2008). Human resource management (11th ed.). New Delhi: Prentice-Hall of India Private Ltd.

Dreher, F.G., \& Dougherty, T.W. (2002). Human resource strategies: A behavioural perspective for the general manager. New York: McGraw-Hill/Irwin.

Ezirim, A.C., Briggs, B.R., \&Maclayton, D.W. (2004).Research methodology for management and social sciences. Nigeria: McComputer Press.

Frankfort-Nachmias, C.,\&Nachmias, D. (2009). Research methods in the social sciences $\left(5^{\text {th }}\right.$ ed.).U.K: Hodder Education.

Gatewood, R.D., \&Feild, H.S (2001). Human resource selection $\left(5^{\text {th }}\right.$ ed.). Cincinnati, Ohio: South-Western Publishing.

Gberevbie, D.E. (2008). Employee retention strategies and organisational performance. Ife PsychologiA, 16(2), 131-152. 
Gomez-Mejia, R. L.,\&Balkin, B. D. (1992). Compensation, organisational strategy, and firm performance. Cincinnati: South-western Publishing.

Gomez-Mejia, R. L., Balkin, B.D \&Cardy, L.R. (2001). Managing human resources ( $3^{\text {rd }}$ ed.). New Jersey: Prentice - Hall Inc.

Griffeth, R.W., Hom, P.W., \&Gaertner, S. (2000).A meta-analysis of antecedents and correlates of employee turnover: Update, moderator, tests and research implications for the next millennium. Journal of Management, 26(3), 463-488.

Guilford, J. P. (1954). Psychometric methods. New York: McGraw- Hill.

Hausknecht, J., Rodda, J.M., \& Howard, M.J. (2008). Targeted employee retention: Performance-based and job-related differences in reported reasons for staying. Working Paper Series 08-06. Centre for Advanced Human Resource Studies, Cornell University.

Heneman, H.G.,\& Judge, T.A. (2006). Staffing organisation $\left(5^{\text {th }}\right.$ ed.). New York: McGraw-Hill/ Irwin.

Ho, R. (2006). Handbook of univariate and multivariate data analysis and interpretation with SPSS. New York: Taylor and Francis Group

Incomes Data Services (IDS) (2004). Improving staff retention. IDS HR Studies No. 765.

Khan, M.A. (2010). Effects of human resource management practices on organisational performance: An empirical study of oil and gas industry in Pakistan. European Journal of Economics, Finance and Administrative Sciences, Issue 24, 157-175.

Kothari, C.R. (2004). Research methodology, methods and techniques (2 ${ }^{\text {nd }}$ ed.). Delhi: New Age International.

Lawal, A. A. (2011). Strategic importance of Nigerian small \& medium enterprises: Separating reality from the myth. An Inaugural Lecture delivered on $30^{\text {th }}$ March; at the Lagos State Polytechnic.

Luthans, F. (1998). Organisational behaviour ( $8^{\text {th }}$ ed.). New York: Irwin/McGraw-Hill.

Maertz, C.P., \&Griffeth, R.W. (2004). Eight motivational forces and voluntary turnover: A theoretical synthesis with implications for research. Journal of Management,30(5), 667683.

Marks, H. (2001). Money-that's not what they want. HR-ESource. May, 7. Retrieved from:www.hr-esource.com.

Mathis, R.L., \& Jackson, J.H. (2004). Human resource management (10 ${ }^{\text {th }}$ ed.). Cincinnati, Ohio: South-Western Publishing.

McEvoy, G.M., \& Cascio, W.F. (1987). Strategies for reducing employee turnover: A metaanalysis. Journal of Applied Psychology,30, 342-353.

Mitchell, M. L., \& Jolley, J. M. (2008). Research design explained (6 ${ }^{\text {th }}$ ed.). Belmont-USA: Thomson and Wadsworth

Oghojafor, A.B., Lawal, A.A., \&Adebakin, M.A. (2010). Global economic meltdown and organisational performance of Nigerian small and medium enterprises. A Paper Presented at the $7^{\text {th }}$ International Conference on Small and Medium Enterprises in Malaysia.

Okoh, A.O. (1998). Personnel and human resource management in Nigeria. Lagos: Amfitop Books.

Ongori, H. (2007). A review of the literature on employee turnover. African Journal of Business Management, June, 49-54. 
Pfeffer, J. (1994). Competitive advantage through people. Boston: Harvard Business School Press.

Saks, A.M., Wiesner, W.H., \& Summers, R.J. (1996). Effects of job previews and compensation policy on applicant attraction and job choice. Journal of Vocational Behaviour,49(1), 6885.

Samuel, M.O., \&Chipunza, C. (2009). Employee retention and turnover: Using motivational variables as a panacea. African Journal of Business Management,3(8), 410- 415.

Sapru, R.K. (2009). Administrative theories and management thought ( $2^{\text {nd }}$ ed.). New Delhi: PHI Learning Private Limited.

Shahzad, K., Mumtaz, H., Hayat, K., \& Khan, M.A. (2010). Faculty workload, compensation management and academic quality in higher education of Pakistan: Mediating role of job satisfaction. European Journal of Economics, Finance and Administrative Sciences, Issue 27, 111-119.

Sherman, K. (2017). Choosing the appropriate research method and research design [Online Discussion Group]. Retrieved from https://class.waldenu.edu

Steel, R.P., Griffeth, R.W., \&Hom, P.W. (2002). Practical retention policy for the practical manager. Academy of Management Executive, 16(2), 149-164.

Taplin, I.M., Winterton, J., \&Winterton, R. (2003). Understanding labour turnover in a labour intensive industry: Evidence from the British clothing industry. Journal of Management Studies, 40 (4), 1021-1046.

Taylor, S.G. (1994). Realistic job previews in the trucking industry. Journal of Management Issue, 6(4), 457-473.

Thio, S. (2000). Retention strategies in turbulent times. Research and Practice in Human Resource Management, 8(2), 135-152.

Torrington, D., Hall, L.,\& Taylor, S. (2008). Human resource management ( $^{\text {th }}$ ed.). UK: Pearson Education Ltd.

Uwaoma, C.N., Udeagha, C.F., \&Madukwe, A.U. (2011). Development and factorial validation of spouse rape inventory. European Journal of Social Sciences, 19 (2), 261-267.

Wanous, J.P. (1989). Installing a realistic job preview: Ten tough choices. Personnel Psychology, 42,117-134. 